\title{
Early treatment with infliximabin patients with juvenile idiopathic arthritis
}

\author{
TV Sleptsova, El Alexeeva, SI Valieva, TM Bzarova, KB Isayeva, RV Denisova, EV Mitenko \\ From 18th Pediatric Rheumatology European Society (PReS) Congress \\ Bruges, Belgium. 14-18 September 2011
}

\section{Background}

Treatment of patients with JIA with DMARDs is started immediately after diagnosis, resulting in more effective suppression of disease activity. TNF blockers are recommended in cases of active JIA after the unsuccessful use of DMARDs. The exact role of these agents in the treatment of early-stage JIA is unknown.

\section{Objective}

To evaluate the efficacy of infliximab in patients $(n=100)$ with early and long-standing JIA.

\section{Methods}

100 (60 with early and 40 with long-standing JIA) patients who didn't respond to DMARDs received infliximab 6-7 $\mathrm{mg} / \mathrm{kg}$ q8wks. Evaluation of efficacy included $30 \%, 50 \%$ and $70 \%$ improvement by the ACR-pedi criteria and remission.

\section{Results}

At 54 week $100 \%$ and $87.5 \%$ patients with early and long-standing JIA respectively achieved at least 50\% response. After 2 years ACR-Pedi 70/90 response to infliximab was recorded in all patients with early JIA and $100 \% / 88.9 \%$ of patients with long-standing JIA respectively. At weeks 54 following infliximab treatment, $89 \%$ and $60 \%$ of patients with early and long-standing JIA achieved remission. At the end of the second year, remission was reported in $97 \%$ of children with early JIA and $72 \%$ of patients in the second group. $34 \%$ of the patients discontinued due to an adverse event, mainly lack of efficacy (23 patients) and hypersensitivity reactions (11 patients).

\section{Conclusions}

This 2-years study suggest using IFX as initial treatment for patients with recent onset JIA is more effective than reserving it for patients with long-standing JIA. No difference between groups in adverse events and secondary inefficacy were observed.

Published: 14 September 2011

\section{doi:10.1186/1546-0096-9-S1-P113}

Cite this article as: Sleptsova et al.: Early treatment with infliximabin patients with juvenile idiopathic arthritis. Pediatric Rheumatology 20119 (Suppl 1):P113.
Submit your next manuscript to BioMed Central and take full advantage of:

- Convenient online submission

- Thorough peer review

- No space constraints or color figure charges

- Immediate publication on acceptance

- Inclusion in PubMed, CAS, Scopus and Google Scholar

- Research which is freely available for redistribution
() Biomed Central

\section{() Biomed Central}

